\title{
Mineralogy of a Mudstone at Yellowknife Bay, Gale Crater, Mars
}

Authors: D.T. Vaniman ${ }^{1 *}$, D.L. Bish ${ }^{2}$, D.W. Ming ${ }^{3}$, T.F. Bristow ${ }^{4}$, R.V. Morris ${ }^{3}$, D. F. Blake ${ }^{4}$, S. J. Chipera ${ }^{5}$, S.M. Morrison ${ }^{6}$, A.H. Treiman ${ }^{7}$, E.B. Rampe ${ }^{3}$, M. Rice ${ }^{8}$, C.N. Achilles ${ }^{9 \dagger}$, J. Grotzinger $^{8}$, S.M. McLennan ${ }^{10}$, J. Williams s ${ }^{11}$, J. Bell III ${ }^{12}$, H. Newsom ${ }^{11}$, R.T. Downs ${ }^{6}$, S. Maurice $^{13}$, P. Sarrazin ${ }^{14}$, A.S. Yen ${ }^{15}$, J.M. Morookian ${ }^{15}$, J.D. Farmer ${ }^{12}$, K. Stack ${ }^{8}$, R.E. Milliken $^{16}$, B. Ehlmann ${ }^{8,15}$, D.Y. Sumner ${ }^{17}$, G. Berger ${ }^{13}$, J.A. Crisp ${ }^{15}$, J.A. Hurowitz ${ }^{10}$, R. Anderson $^{15}$, D. DesMarais ${ }^{4}$, E.M. Stolper ${ }^{8}$, K.S. Edgett ${ }^{18}$, S. Gupta $^{19}$, and N. Spanovich ${ }^{15}$, MSL Science Team

Institutions: ${ }^{1}$ Planetary Science Institute, Tucson, AZ, 85719, USA

${ }^{2}$ Department of Geological Sciences, Indiana University, Bloomington, IN, 47405, USA

${ }^{3}$ NASA Johnson Space Center, Houston, TX, 77058, USA

${ }^{4}$ NASA Ames Research Center, Moffett Field, CA, 94035, USA

${ }^{5}$ Chesapeake Energy, Oklahoma City, OK, 73154, USA

${ }^{6}$ Department of Geosciences, University of Arizona, Tucson, AZ, 85721, USA

${ }^{7}$ Lunar and Planetary Institute, Houston, TX, 77058, USA

${ }^{8}$ Division of Geologic and Planetary Sciences, California Institute of Technology, Pasadena, CA, 91125, USA

${ }^{9}$ ESCG/UTC Aerospace Systems, Houston, TX, 77058, USA

${ }^{10}$ Department of Geosciences, SUNY Stony Brook, Stony Brook, NY, 11794, USA

${ }^{11}$ Institute of Meteoritics, University of New Mexico, Albuquerque, NM, 87131, USA

${ }^{12}$ School of Earth and Space Exploration, Arizona State University, Tempe, AZ, 85287, USA

${ }^{13}$ Institut de Recherche en Astrophysique et Planétologie (IRAP), Universite de Toulouse/CNRS, Toulouse, 31400, France

${ }^{14}$ SETI Institute, Mountain View, CA, 94043, USA

${ }^{15}$ Jet Propulsion Laboratory, California Institute of Technology, Pasadena, CA 91109, USA

${ }^{16}$ Department of Geological Sciences, Brown University, Providence, RI, 02912, USA

${ }^{17}$ Department of Earth and Planetary Sciences, University of California, Davis, CA, 95616, USA

${ }^{18}$ Malin Space Science Systems, San Diego, CA, 92121, USA

${ }^{19}$ Department of Earth Science and Engineering, Imperial College London, SW7 2AZ, UK

*Correspondence to: dvaniman@psi.edu

${ }^{\dagger}$ Current address: Department of Geological Sciences, Indiana University, Bloomington, IN, 47405, USA

${ }^{7}$ MSL Science Team authors and affiliations are listed in the supplementary materials. 


\begin{abstract}
Sedimentary rocks at Yellowknife Bay (Gale Crater) on Mars include mudstone sampled by the Curiosity rover. The samples, John Klein and Cumberland, contain detrital basaltic minerals, Casulfates, Fe oxide/hydroxides, Fe-sulfides, amorphous material, and trioctahedral smectites. The John Klein smectite has basal spacing of $\sim 10 \AA$ indicating little interlayer hydration. The Cumberland smectite has basal spacing at $\sim 13.2 \AA$ as well as $\sim 10 \AA$. The $\sim 13.2 \AA$ spacing suggests a partially chloritized interlayer or interlayer $\mathrm{Mg}$ or Ca facilitating $\mathrm{H}_{2} \mathrm{O}$ retention. Basaltic minerals in the mudstone are similar to those in nearby eolian deposits. However, the mudstone has far less Fe-forsterite, possibly lost with formation of smectite plus magnetite. Late Noachian/Early Hesperian or younger age indicates that clay mineral formation on Mars extended beyond Noachian time.
\end{abstract}

\title{
Introduction
}

The recent decade of orbiter- and rover-based studies of ancient sedimentary rocks on Mars has revealed a diverse mineralogy that constrains the nature and timing of early environments in the history of the planet $(1,2,3)$ These studies provide a starting point for considering the habitability of Mars, based on an understanding of the aqueous geochemistry and mineralogy of rocks placed within a geologic framework $(4,5)$. Such an approach has been adopted by the Mars Science Laboratory (MSL) mission, where the science payload and advanced capabilities of the Curiosity rover were designed for assessment of past habitability (6).

Mission goals for MSL placed high priority on aqueous-system mineralogy, particularly clay minerals and sulfate salts (6). The mission concept for the landing site in Gale Crater was to leave the landing spot quickly and drive to Aeolis Mons, a central mound informally known as Mount Sharp. Interpretation of Mars Reconnaissance Orbiter CRISM (Compact Reconnaissance Imaging Spectrometer for Mars) visible-near infrared spectroscopy suggests the presence of hydrated minerals in sedimentary layers at the base of the mound (7). However, soon after landing a contact between three different geologic units, one with relatively high thermal inertia, was recognized within $\sim 450 \mathrm{~m}$ of the landing spot, just beyond the alluvial lobe of the Peace Vallis fan (8). The decision to drive away from Mount Sharp toward this location has provided early samples of a mudstone that contains both clay minerals and sulfate salts.

The John Klein and Cumberland drill samples were collected from the Sheepbed mudstone member of the sedimentary Yellowknife Bay formation, which is interpreted as a shallow lacustrine deposit (8). John Klein and Cumberland are the second and third solid samples, respectively, collected by the MSL rover Curiosity. The first sample, from an eolian deposit named Rocknest, is $\sim 60 \mathrm{~m}$ west of the mudstone drill locations. The loose Rocknest deposit (9) had been used to commission Curiosity's scoop sampling system and the lithified John Klein sample was used to commission the drill. Curiosity's sampling system delivers both scooped and drilled powders to the same set of sieves (10). All scooped or drilled samples were sieved to $<150 \mu \mathrm{m}$ and portions were analyzed by the Chemistry and Mineralogy (CheMin) X-ray diffraction (XRD) and X-ray fluorescence (XRF) instrument (11) and the Sample Analysis at Mars (SAM) quadrupole mass spectrometer/gas chromatograph/tunable laser spectrometer suite of instruments $(12,13)$. 
CheMin XRD data are the focus of this paper. Although the CheMin XRD instrument is the prime mineralogy tool carried by Curiosity, constraints on the mudstone mineralogy are provided by the temperatures at which volatiles are released in SAM evolved gas analyses, particularly $\mathrm{H}_{2} \mathrm{O}$ release profiles (13). Other instruments on Curiosity provide additional insight into mineralogy. Mastcam $(14,15)$ multispectral images are capable of sand-size resolution and potential identification of certain hydrated minerals using short-wavelength near-IR filters (16). ChemCam has a narrow laser beam that can target veins and nodules for remote chemical analysis by laser-induced breakdown spectroscopy (LIBS), with sensitivity to many elements including hydrogen $(17,18)$; this capability can aid in constraining mineral compositions where individual minerals are $\sim 0.5 \mathrm{~mm}$ or larger and is particularly sensitive to alkali and alkaline-earth elements (19). The MSL alpha-particle X-ray spectrometer (APXS) has proven heritage from previous missions and provides sensitivity to a wide range of common rock-forming elements (20), although analysis spot resolution is $\sim 1.7 \mathrm{~cm}$ diameter, providing a bulk chemical analysis rather than mineral analysis for most samples. We use the results from APXS to constrain the composition of the X-ray amorphous components of the mudstone. The Mars Hand Lens Imager (MAHLI) provides high-resolution images, to $14 \mu \mathrm{m}$ per pixel, with Bayer pattern color that can simulate hand-lens or close-up sample analysis (21).

Figure 1 shows Mastcam and MAHLI images of the boreholes and drill powders for John Klein and Cumberland. Cumberland (Fig. 1C) was targeted after John Klein, in order to analyze a part of the mudstone with fewer sulfate veins and a greater abundance of resistant concretions, including nodules and hollow nodules that are regarded as early cementation. The two drill holes are $\sim 3 \mathrm{~m}$ apart. Powders of both mudstone samples are notably gray in color, unlike the reddish weathering and/or dust evident on the surface of the mudstone. This reddish surface of the mudstone did not contribute to either drill sample, for the auger does not pass powder into the sampling system until it is $\sim 1.5 \mathrm{~cm}$ into the drill target (10).

\section{Mineralogical Analysis and Quantitative Mineralogy}

The X-ray diffraction patterns for John Klein and Cumberland are compared in Fig. 2A. We quantified the crystalline components, other than smectites, in John Klein and Cumberland (Table 1) by using whole-pattern fitting and Rietveld analysis (Figs. 2B,C); smectites and the amorphous component were quantified using a modified version of the FULLPAT program (22). These methods are described in (23) and elaborated in (24). Conversion of the two-dimensional images of Debye diffraction rings on the CCD to one-dimensional diffraction patterns was done in the same manner for Rocknest, John Klein, and Cumberland. For all three samples, we obtained unit-cell parameters (Table 2) and phase compositions (Table 3) for major phases. The unit-cell parameter and phase composition data reported for Rocknest, John Klein, and Cumberland were processed in the same manner and are therefore comparable.

An independent assessment of the abundance of smectite and amorphous material can be obtained from the fixed or cell-parameter-constrained chemical compositions of the phases listed in Table 1 and the total sample chemical composition from APXS analysis of the drill tailings. This approach (24) uses a mass-balance calculation with XRD constraints on crystal chemistry $(25,26)$ and, for the present study, model smectite compositions, to estimate the composition of the amorphous component. Additional constraints on smectite abundance come from SAM 
evolved gas analysis, where the amount of $\mathrm{H}_{2} \mathrm{O}$ released at higher temperatures $\left(\sim 400-835^{\circ} \mathrm{C}\right)$ can be related to dehydroxylation of various clay minerals (13). Within estimated errors these three methods agree, but in this paper we focus on the XRD estimates (Table 1).

None of the coarse (>mm width) veins that cross the Sheepbed member (8) were sampled for CheMin and SAM analysis. However, Mastcam near-IR spectral filters are sensitive to hydration in certain minerals (27), and this method (24) was used to analyze veins where ChemCam and APXS data indicated that Ca-sulfate phases are present. This allows mapping of inferred gypsum distributions in the veins that were not sampled for CheMin and SAM analysis.

The sedimentologic context of the mudstone is complex. Observations of the mudstone (8) lead to interpretation of an early-diagenetic association of nodules, hollow nodules, and raised ridges that are crosscut by late-diagenetic fractures filled with light-toned $\mathrm{Ca}$-sulfates ( $\mathrm{S}-\mathrm{Ca}$ association in these veins was identified with ChemCam). Early-diagenetic hollow nodules are filled with light-toned sulfates only where intersected by late-diagenetic light-toned microfractures $(8,19)$. MAHLI images show that the John Klein drill spot had a surface footprint (1.6 cm diameter) with $\sim 3.9 \%$ hollow nodules, $\sim 2.5 \%$ solid nodules, and $\sim 14.5 \%$ light-toned sulfate, whereas the Cumberland drill spot had $\sim 8.5 \%$ hollow nodules, $\sim 2.2 \%$ solid nodules, and no evident light-toned sulfate. Estimates of light-toned sulfate abundances from pre-drilling images can be deceptive because their three-dimensional distribution is dependent on variable occurrence of thin veins that may or may not be visible on the dust-mantled surface. A more accurate survey of the distribution and abundance of light-toned sulfates is obtained by analysis of drill-hole wall images (24), at least to the depth exposed (the lower part of each drill hole contains some debris).

The borehole samples John Klein and Cumberland provide adequate sampling of the mudstone matrix with a partial sampling of features that are both early-diagenetic (nodules and hollow nodules) and late-diagenetic (light-toned veins). The drill did not sample any earlydiagenetic raised ridges. The raised ridges were identified in LIBS and APXS analyses as including an $\mathrm{Mg}-\mathrm{Fe}-\mathrm{Cl}$ rich component; in images they appear to have an isopachous filling of several layers and may be mineralogically complex (19). Without direct sampling and CheMin $\mathrm{XRD}$ analysis, knowledge of mineralogy in the raised ridges is speculative and is not addressed here.

\section{Silicates other than Smectites}

Several detrital silicate minerals in the mudstone bear a strong resemblance to those found in the Rocknest eolian deposit (Tables 2, 3). Fe-forsterite, plagioclase, pigeonite, and augite are generally similar between Rocknest, John Klein, and Cumberland, suggesting similar mafic sources. Presence of pigeonite indicates mafic sources that were basaltic. However, XRD analyses of the mudstone samples reveal presence of orthopyroxene as well as clinopyroxenes, indicating a source of some mafic minerals that is either absent from or very minor in the nearby eolian deposit.

It is notable that Fe-forsterite is almost absent in Cumberland and its abundance in John Klein is much lower than in Rocknest. Figure 1B shows that the reddish Rocknest sample coats the 
walls of the scoop that is filled with the John Klein drill powder. Testbed operations on Earth suggest that at least $\sim 4 \%$ cross-contamination should be expected between samples. By the time Cumberland was imaged (Fig. 1D), the red Rocknest powder was almost gone, so the sampling system had been largely cleared of this contaminant in processing John Klein. Progressive dilution and a stronger cleaning cycle between John Klein and Cumberland left little if any Rocknest contamination in Cumberland - and conversely, some of the Fe-forsteritic olivine present in the John Klein sample might be contamination from the Rocknest sample.

\section{Phyllosilicates}

CheMin XRD data reveal the presence of phyllosilicates in John Klein and Cumberland (Fig. 2A). A broad 001 diffraction peak in the John Klein XRD pattern extends from 12 to $9.4 \AA$, corresponding with the large interlayer spacing of a 2:1 smectite. This broad range of 001 diffraction is common to a variety of phyllosilicates, but the breadth of this peak (and the lack of other well-defined peaks, such as an 002 peak at $5 \AA$ ) argue against the presence of wellcrystallized phyllosilicates such as mica or illite. Well-defined diffraction peaks for kaolinite or chlorite-group minerals at $7 \AA$ are absent. A smectite with similar diffraction properties is present in Cumberland, although the low-angle region includes a second peak ranging from $\sim 12$ $17 \AA$ with a maximum at $\sim 13.2 \AA$. This larger interlayer spacing in the Cumberland XRD pattern is a noteworthy characteristic.

The interlayer spacing in a smectite, revealed by the broad 001 peak, is affected by the layer charge, the nature of the interlayer cation(s) (typically $\mathrm{K}, \mathrm{Na}$, and/or Ca; less commonly $\mathrm{Mg}$ ), the hydration state of the interlayer cations, and the possible presence of chloritic interlayers. The layer charge and interlayer cation content of a smectite are relatively stable in solid samples, so changes in interlayer spacing are mostly dependent on relative humidity. Modeling and experimental studies $(28,29)$ suggest that if exposed at Mars surface conditions, smectites can go through diurnal and seasonal hydration cycling, with substantial dependence of the amount of hydration on the nature of the interlayer cation. For example, Ca-smectite will hold more interlayer $\mathrm{H}_{2} \mathrm{O}$ than Na-smectite at the same conditions (30). The John Klein and Cumberland samples inside the body of Curiosity were exposed to higher and less variable temperature (a diurnal range of 5 to $25^{\circ} \mathrm{C}$ ) than they were in situ. These temperatures yield very low relative humidities and dehydration should be favored. The position and breadth of the 001 diffraction peak in the John Klein sample have not changed over 30 sols of analysis following collection, but at $10 \AA$ this smectite appears to be largely dehydrated and little or no change would be expected. The larger 001 spacing in Cumberland has also been static, over 28 sols of analysis; the preservation of this wider spacing suggests a difference in the interlayer composition of the smectite in Cumberland compared with John Klein.

Possible explanations for persistent larger interlayer spacing in Cumberland include smectite having hydrated interlayers with $\mathrm{H}_{2} \mathrm{O}$ molecules retained by high hydration-energy interlayer cations, possibly $\mathrm{Mg}^{2+}(28)$ or $\mathrm{Ca}^{2+}(30)$, and partial pillaring of the interlayer by metal-hydroxyl groups, as with incipient chloritization (31), that would prevent collapse. The nodule-bearing portions of the mudstone that were drilled for sampling pass laterally into mudstone with earlydigenetic $\mathrm{Mg}$-rich raised ridges described above. These could be sources of $\mathrm{Mg}$ for cation exchange or incipient chloritization, focused more on Cumberland than on John Klein. Cation 
exchange occurs readily, with the interlayer cation largely reflecting the dominant cation in solution. Incipient chloritization by fixation of $\mathrm{Mg}$-hydroxl groups can occur under surficial conditions when exposed to $\mathrm{Mg}$-rich alkaline fluids, a process observed in some saline lakes (32). Hydrothermal fluids may induce this change as well (33).

X-ray diffraction analysis of clay minerals in terrestrial laboratories has the advantage of additional sample processing, such as preparation of oriented mounts, controlled variation of relative humidity, treatment with ethylene glycol, and heat treatment. These treatments are not possible in CheMin on Mars. In addition, a substantial component of smectite classification is in determination of trioctahedral or dioctahedral crystal structure (the range from full to $2 / 3$ occupancy of sites in the octahedral sheet), but this is generally accomplished by analysis of the $06 l$ diffraction band at $\sim 1.54 \AA$ (trioctahedral, $\sim 71^{\circ} 2 \theta$ Co K $\alpha$ ) to $\sim 1.50 \AA$ (dioctahedral, $\sim 73^{\circ} 2 \theta$ $\mathrm{Co} \mathrm{K} \alpha)$. This is beyond the diffraction range of the CheMin CCD detector $\left(\sim 50^{\circ} 2 \theta\right)$. However, other components of the diffraction pattern correlate similarly with this structural difference. The position of the maximum in the $02 \mathrm{l}$ band, at $\sim 22.5^{\circ}$ to $23.1^{\circ} \mathrm{Co} \mathrm{K \alpha}$, corresponds with the range from trioctahedral to dioctahedral structures (Fig. 3). The $02 l$ two-dimensional diffraction band is asymmetric, is often overlapped by diffraction peaks from other phases (e.g., augite), and therefore is not as easy to measure as $06 l$. However, this band provides similar information, as its position is related to the $b$ unit-cell parameter in the same way as the $06 l$ band. The $02 l$ diffraction band maximum for the John Klein and Cumberland samples (Fig. 3) is at $22.5^{\circ}$, indicative of a trioctahedral clay mineral such as saponite or Fe-saponite and not of dioctahedral forms such as montmorillonite. Some Fe-bearing dioctahedral smectites such as nontronite have similar $02 l$ bands, but the fit is not as good as with saponite.

\section{Oxide and Sulfide Minerals}

Magnetite is the prominent oxide phase in John Klein and Cumberland, as it is at Rocknest (23). Magnetite is present at $3.8 \mathrm{wt} \%$ in the John Klein sample and $4.4 \mathrm{wt} \%$ in Cumberland (Table 1). These abundances are significantly higher than in Rocknest (1.5 wt\%). As a basic observation, concentration of detrital magnetite in sedimentary mudstones is surprising. Grains of magnetite $\left(\rho \sim 5 \mathrm{~g} / \mathrm{cm}^{3}\right)$ are not expected to be enriched in very fine grained detrital sedimentary rocks otherwise composed of olivine, pyroxene, and feldspar $(\rho \sim 2.7-3.7)$. By reason of hydraulic equivalence, grains of higher density may be present but are expected to be smaller in size, and enrichment should not occur (34). Other factors are required for selective enrichment such as free settling of grains in turbulent flow, selective entrainment of grains from a granular bed by flowing water, and shearing of grains in a moving granular dispersion (35). However, because the Sheepbed mudstone likely formed by non-turbulent settling of fines from suspension in a body of standing water (8), we expect that none of these processes would have been influential in causing a hydraulic enrichment of heavy minerals. The relatively high abundance of magnetite in the Sheepbed mudstone may have been caused by authigenesis. Authigenesis of magnetite is further suggested by the observation that high magnetite abundance is associated with loss of Fe-forsterite and the appearance of smectites.

Unit-cell parameters of magnetite in the mudstone are about $0.2 \%$ smaller than for ideal magnetite, with a unit-cell edge of 8.38 versus $8.39 \AA$ A. A possible explanation of the smaller cell 
size is partial ( 20\%) oxidation of the ferrous iron, toward the ferric defect-spinel maghemite $(8.33 \AA)$ in which some Fe sites are vacated to preserve charge balance. Alternatively, substitution of smaller cations such as $\mathrm{Cr}, \mathrm{Mg}$, or $\mathrm{Al}$ could account for a smaller unit cell, although it is not clear whether sufficient amounts of these are present.

In addition to magnetite, the Rietveld refinements are consistent with small amounts of ilmenite and hematite in the mudstone samples. Also present is akaganeite, $\beta-\mathrm{FeO}(\mathrm{OH}, \mathrm{Cl})$, which is a possible oxide host for $\mathrm{Cl}$. It has been previously suggested (36), based on midinfrared and visible/near-infrared spectra, that akaganeite may be a precursor to hematite observed from orbit on Mars, but the same study concluded that goethite was a more likely precursor. However, the mudstone at Yellowknife Bay is not a typical martian surface material and the colors of the mudstone beneath its reddish dust mantle are substantially different (Fig. 1). Akaganeite was detected in both mudstone samples, but not at Rocknest. Akaganeite at its type locality on Earth (37) occurs as an alteration product of pyrrhotite, a sulfide that is also found in the Yellowknife Bay mudstone but not in the Rocknest sample (Table 1). Occurrence of this association at Yellowknife Bay may be evidence of a similar alteration relationship. Somewhat higher abundance of akaganeite in Cumberland than in John Klein (Table 1) suggests that it could be a component of concretion formation, especially of hollow nodules that appear to be twice as abundant at Cumberland as at John Klein.

\section{Sulfate Minerals}

Veins of Ca-sulfate, believed to be gypsum, have been detected by the MER rover Opportunity at the western edge of Cape York on the rim of Endeavour Crater (38). Calcium sulfate hydrates, including both gypsum and bassanite, have been inferred from OMEGA and CRISM orbital spectroscopy in multiple locations on Mars $(39,40)$, but with a lack of hydration bands at visible-near infrared wavelengths anhydrite has been elusive.

CheMin XRD data show that the Sheepbed mudstone contains bassanite and anhydrite (Table 1). Anhydrite was also detected in the Rocknest eolian deposit. We have found no XRD evidence for gypsum in either Rocknest or the two mudstone samples. However, Mastcam hydration index measurements are consistent with the presence of gypsum in some of the veins crossing the mudstone, showing that the vein system might contain all three of the principal Ca-sulfate phases. Specifically, Mastcam's longest-wavelength filter $(1013 \pm 21 \mathrm{~nm})$ can detect the $2 v_{1}+v_{3}$ $\mathrm{H}_{2} \mathrm{O}$ combination absorption band and/or the $3 \mathrm{v} \mathrm{OH}$ overtone absorption band in specific hydrated minerals $(16,27,41)$. Calibrated Mastcam spectra show evidence for hydration associated with some light-toned, Ca-sulfate bearing features in the Sheepbed unit, including some veins (Fig. 4A,B) and some fillings within hollow nodules. However, the hydration signature is not universal in these light-toned features; several narrow veins observed in the John Klein vicinity show no evidence for hydration. From comparisons with laboratory reflectance spectra of Ca-sulfate minerals convolved to Mastcam bandpasses (Fig. 4C), the hydration signature near $1013 \mathrm{~nm}$ is consistent with the presence of gypsum, but not bassanite or anhydrite (24). The presence of some Ca-sulfate veins that exhibit the Mastcam hydration signature and others that do not, with apparent lower hydration in thinner veins, is in accord with XRD observation in the drill samples of bassanite and anhydrite but not gypsum. 
Before the John Klein drill sample was collected, observations by LIBS, supported by APXS analyses of some veins, had indicated widespread association of $\mathrm{Ca}$ and $\mathrm{S}$ in light-toned veins and filling hollow nodules in Yellowknife Bay. The LIBS and APXS data and Mastcam spectral interpretations suggest hydrogen associated with some but not all of these light-toned materials. The drill locations for John Klein and Cumberland were deliberately targeted to collect samples of the mudstone matrix with as little sulfate veining as possible (Figures 1A and 1C). Nevertheless, hairline fractures and fillings within hollow nodules were observed on borehole walls (24) and these are likely the principal or sole hosts of Ca-sulfate minerals in the John Klein and Cumberland samples.

Bassanite does not have a stability field at pressures less than $235 \mathrm{MPa}$ (42), far in excess of the maximum pressure ( $50 \mathrm{MPa})$ that would be attained if the Sheepbed mudstone had been buried under $\sim 5 \mathrm{~km}$ of sediment (a possibility because the mudstone could be exhumed from beneath the 5-km-high stratigraphy of Mt. Sharp). Bassanite in the mudstone is not in equilibrium, but it may persist for long periods because of the unique surface conditions on Mars. Bassanite is relatively rare on Earth because it readily hydrates to form gypsum, even at low relative humidity. However, the very low vapor pressure of $\mathrm{H}_{2} \mathrm{O}$ in the atmosphere of Mars may favor persistence of bassanite $(43,44)$. Although nominal near-equatorial surface conditions are unlikely to desiccate gypsum to form bassanite (44), moderate increase in temperature or decrease in $\mathrm{P}_{\mathrm{H} 2 \mathrm{O}}$ could lead to destabilization of gypsum and formation of bassanite $(45,46)$.

Bassanite forms in many different ways on Earth. Examples include dissolutionreprecipitation after gypsum in sabkha environments (47), gypsum dehydration in endoevaporitic microbial communities under slightly alkaline conditions (48), alteration of carbonates in acidsulfate systems (49), and dehydration of gypsum dunes (50) or arid sedimentary rocks (51) in desert environments. Bassanite of undetermined origin also occurs along with gypsum in soil of the Transantarctic Mountains (52). In most of these bassanite occurrences on Earth, the associated or precursor Ca-sulfate is gypsum because bassanite is often a product of gypsum dehydration. In these representative studies, association of bassanite with anhydrite, as in the John Klein sample, does not occur and is apparently rare. This is probably because temperatures of anhydrite formation are generally high enough not to favor a metastable bassanite precursor, and hydration of anhydrite is likely to go directly to gypsum.

Anhydrite is a common mineral on Earth, although it hydrates to form gypsum in sufficiently humid environments. Hydration rates for "soluble anhydrite" (having remnant channel structure similar to bassanite) are relatively rapid; hydration rates are much slower for insoluble anhydrite (53). Where activity of pore waters is above $\sim 0.9$ and up to 1.0 , anhydrite is the stable Ca-sulfate mineral at burial depths where temperatures rise above $\sim 50-58{ }^{\circ} \mathrm{C}($ e.g., (54)). The temperature of this transition decreases as $\mathrm{H}_{2} \mathrm{O}$ activity decreases, and thus the occurrence of anhydrite, in the absence of other information, can be a poor guide to past temperatures. However, if an anhydrite occurrence carries other information that constrains the activity of water, it is a reasonable indicator of elevated temperature. Moreover, persistence of anhydrite, as of bassanite, indicates a lack of post-formation hydration. 
Low-pH acid-sulfate weathering has long been proposed for many locations on Mars (e.g., (55)). Acid-sulfate weathering was likely to have been much more pervasive in the Noachian, when major impacts had substantial influence on hydrosphere chemistry (56). In the well-studied Burns formation of Meridiani Planum the occurrence of Fe-sulfate phases such as jarosite is evidence of such conditions, with diagenesis related to persistent groundwater of high ionic strength (57). The absence of Fe-sulfates at John Klein and Cumberland, and the presence of Casulfates instead, is evidence of an environment with low ionic strength and circum-neutral $\mathrm{pH}$.

\section{The X-ray Amorphous Component}

The amorphous component of the mudstone may represent soil or eolian fines accumulated along with crystalline detritus in the mudstone, but the nature and origin of the amorphous component is poorly known. Estimated composition of the amorphous component in the mudstone (24) varies depending on the assumed composition of the phyllosilicates, but generally indicates a relatively Si-poor material enriched in $\mathrm{Fe}, \mathrm{S}, \mathrm{Cl}$, and $\mathrm{P}$. The estimated compositions of amorphous material in the mudstone are approximately similar to the amorphous component of the Rocknest eolian deposit $(24,25)$, but possibly modified during diagenesis in the mudstone, including smectite formation and subsequent cation exchange or other interlayer adjustments.

\section{Implications of the Sheepbed Mudstone Mineral Assemblage}

Detrital plagioclase, clinopyroxenes, and Fe-forsterite identified by CheMin are generally similar in composition for Rocknest and the mudstone samples John Klein and Cumberland (Table 3). This suggests a common basaltic source for much of the crystalline detritus in both the eolian and mudstone samples. The abundance of magnetite relative to other crystalline phases in the mudstone, however, is in excess of what would be expected for likely basaltic source rocks; normalized to the igneous detrital minerals the magnetite abundance rises from $2.1 \mathrm{wt} \%$ in Rocknest to $8.7 \mathrm{wt} \%$ in John Klein and $9.5 \mathrm{wt} \%$ in Cumberland. Abundant magnetite in the mudstone could indicate either authigenic formation or a mechanism of sedimentary accumulation. The XRD data alone cannot distinguish between these origins, but the mudstone sedimentary context ( 8 ) argues against detrital accumulation of heavy minerals.

Occurrence of gypsum, bassanite, and anhydrite in veins transecting the Yellowknife Bay formation is a disequilibrium association. Persistence of bassanite and anhydrite places limits on post-diagenesis hydration. The Sheepbed mudstone mineralogy favors both formation and preservation of the markers of habitability, having been formed in an aqueous depositional environment with late diagenesis limited to fractures that are isolated from the sediment matrix and with little or no evidence of hydrous alteration following late diagenesis.

The phyllosilicate in John Klein is trioctahedral and likely a saponitic smectite. The clay mineral in Cumberland appears to be genetically related, with an almost identical $02 l$ band, although its interlayer constituents are different. The greater basal spacing of the Cumberland smectite may reflect intercalation of Mg-hydroxy interlayers. Tendency toward interlayer modification may be widespread on Mars, as indicated by spectral studies that point to the common occurrence of smectite/chlorite mixed-layer clay minerals (58). 
Smectites in the mudstone could be detrital, neoformed, or formed from primary phases by authigenic alteration (59). Any of these origins could be compatible with a habitable environment. Relative to other basaltic detrital minerals, Fe-forsterite is disproportionately reduced in John Klein and is almost absent in Cumberland. Assuming an initial presence of olivine in proportions consistent with typical martian basaltic compositions (as at Rocknest (9)), the loss of Fe-forsterite in the mudstone is likely to be a consequence of alteration during authigenic formation of clay minerals. This conclusion is supported by evidence of isochemical alteration (19) as well as evidence of diminished Fe-forsterite abundance associated with proportional increase in magnetite and appearance of clay minerals (Table 1). Analogous alteration of Fe-forsterite is the central process in forming saponitic, trioctahedral clay minerals plus magnetite in chondritic meteorites at temperatures $<100{ }^{\circ} \mathrm{C}(60)$. In the Sheepbed mudstone this process may be related to concretion formation, perhaps associated also with formation of akaganeite. Consequences of such a reaction could include lower Eh, higher $\mathrm{pH}$ that favors intercalation of $\mathrm{Mg}$-hydroxy interlayers in the clay minerals, and possibly production of $\mathrm{H}_{2}$ gas that might account for the voids in the hollow nodules. This scenario of Fe-forsterite "saponitization" is conjectural but worth consideration. The possible formation of $\mathrm{H}_{2}$ gas as part of this process could be another component of habitability, providing a potential energy source for chemolithoautotrophs.

The clay mineral in John Klein has a diffraction pattern suggestive of a smectite that retains swelling capacity, but the signature of the clay mineral in Cumberland is less definitive. Indeed, the larger basal spacing of the clay mineral in Cumberland suggests that it is either hydrated or expanded by some form of intercalation. Furthermore, the persistence of hydration over 30 sols in the warm body of the rover $\left(5-25^{\circ} \mathrm{C}\right)$ at very low $\mathrm{RH}$ is unlikely, so we favor the interpretation of a structural modification. Differences in clay mineralogy over such a short distance between two samples indicate variable diagenetic modification in a mineralogically immature sedimentary rock.

The lack of collapsed and highly ordered illite or chlorite in the Sheepbed member mudstone argues against prolonged, deep burial at elevated temperature. In terrestrial shales development of corrensite or chlorite generally requires alteration temperature in excess of $\sim 60-80{ }^{\circ} \mathrm{C}(\mathrm{e} . \mathrm{g}$., (61)). Absence of such clay mineral modification, beyond the proposed incipient chloritization and partial intercalation of Mg-hydroxy interlayers in clay minerals of the Cumberland sample, suggests alteration at temperatures lower than this. This is a fairly loose constraint at Gale Crater, as complete burial of the crater may have resulted in a maximum burial temperature of only $\sim 75$ ${ }^{\circ} \mathrm{C}$ (62). As noted above, formation of late-diagenetic anhydrite from solutions of low salinity (19) may indicate temperatures above $\sim 50{ }^{\circ} \mathrm{C}$; however, these solutions probably originated at depth from zones at higher temperature. In summary, evidence from the mudstone mineralogy supports modest authigenesis temperatures but does not constrain depth of burial.

The preponderance of clay mineral formation on Mars, with associated habitable environments, has been attributed to Noachian processes (63). Estimated ages for the Sheepbed mudstone are poorly constrained but sediments in the Gale Crater mound are no older than Late Noachin/Early Hesperian (64) and the Yellowknife Bay formation is likely no older than Early Hesperian (8). The Sheepbed member provides an example of an environment where clay mineral formation continued to occur beyond the end of the Noachian Epoch. 


\section{References and Notes}

1. S. W. Squyres, J. P. Grotzinger, J. F. Bell III, W. Calvin, P. R. Christensen, et al., In-situ evidence for an ancient aqueous environment at Meridiani Planum, Mars. Science 306, 17091714 (2004).

2. J.-P. Bibring, Y. Langevin, A. Gendrin, B. Gondet, F. Poulet, et al., Mars Surface Diversity as Revealed by the OMEGA/Mars Express Observations, Science 307, 1576-1581 (2005).

3. S. L. Murchie, J. F. Mustard, B. L. Ehlmann, R. E. Milliken, J. L. Bishop, et al., A synthesis of Martian aqueous mineralogy after 1 Mars year of observations from the Mars Reconnaissance Orbiter. J. Geophys. Res., 114, E00D06, doi:10.1029/2009JE003342 (2009).

4. S. W. Squyres and A. H. Knoll, Sedimentary rocks at Meridiani Planum: Origin, diagenesis, and implications for life on Mars. Earth Planet Sci. Lett. 240, 1-10 (2005).

5. J. Grotzinger, Beyond water on Mars. Nature Geoscience 2, 2331-233 (2009).

6. J. P. Grotzinger, J. Crisp, A. R. Vasavada, R. C. Anderson, C. J. Baker, et al., Mars Science Laboratory Mission and Science Investigation. Space Sci. Rev., 170, p. 5-56, doi: 10.1007/s11214-012-9892-2 (2012).

7. R. E. Milliken, J. P. Grotzinger, and B. J. Thomson, Paleoclimate of Mars as captured by the stratigraphic record in Gale Crater. Geophys. Res. Lett. 37, L04201, doi:10.1029/2009GL041870 (2010).

8. J. P. Grotzinger, D. Sumner, L. Kah, K. Stack, S. Gupta, et al., A habitable fluvio-lacustrine environment at Yellowknife Bay, Gale Crater, Mars. Science (this volume)

9. D. F. Blake, R. V. Morris, G. Kocurek, S. M. Morrison, R. T. Downs, et al., Curiosity at Gale Crater, Mars: Characterization and analysis of the Rocknest sand shadow. Science 341, DOI: 10.1126/science.1239505 (2013).

10. R. C. Anderson, L. Jandura, A. B. Okon, D. Sunshine, C. Roumeliotis, et al., Collecting samples in Gale Crater; an overview of the Mars Science Laboratory sample acquisition, sample handling and processing system. Space Sci. Rev. 170, 57-75, doi: 10.1007/s11214012-9898-9 (2012).

11. D. Blake, D. Vaniman, C. Achilles, R. Anderson, D. Bish, et al., Characterization and Calibration of the CheMin Mineralogical Instrument on Mars Science Laboratory. Space Sci. Rev. 170, 341-399, doi: 10.1007/s11214-012-9905-1 (2012). 
12. P. R. Mahaffy, C. R. Webster, M. Cabane, P. G. Conrad, P. Coll, et al., The Sample Analysis at Mars investigation and instrument suite. Space Sci. Rev. 170, 401-478, doi:

10.1007/s11214-012-9879-z (2012).

13. D. W. Ming, P. D. Archer, Jr., D. P. Glavin, J. L. Eigenbrode, H. B. Franz, et al., Volatile and organic compositions of sedimentary rocks in Yellowknife Bay, Gale Crater, Mars. Science (this volume).

14. M. C. Malin, M. A. Caplinger, K. S. Edgett, F. T. Ghaemi, M. A. Ravine, et al., The Mars Science Laboratory (MSL) Mast-mounted Cameras (Mastcams) Flight Instruments. Lunar Planet. Sci. Conf. 41, abst. \#1123 (2010).

15. J. F. Bell III, A. Godber, M. S. Rice, A. A. Fraeman, B. L. Ehlmann, et al., Initial Multispectral Imaging Results from the Mars Science Laboratory Mastcam Investigation at the Gale Crater Field Site. Lunar Planet. Sci. Conf. 44, abst. \#1417 (2013).

16. M. S. Rice, J. F. Bell III, E. A. Cloutis, A. Wang, S. Ruff, M. A. Craig, D. T. Bailey, J. R. Johnson, P. A. de Souza, Jr., and W. H. Farrand, Silica-rich deposits and hydrated minerals at Gusev Crater, Mars: Vis-NIR spectral characterization and regional mapping, Icarus 205, 375-395, doi:10.1016/j.icarus.2009.03.035 (2010).

17. R. C. Wiens, S. Maurice, B. Barraclough, M. Saccoccio, W. C. Barkley, et al., The ChemCam Instrument Suite on the Mars Science Laboratory (MSL) Rover: Body Unit and Combined System Tests. Space Sci. Rev. 170, 167-227, doi: 10.1007/s11214-012-9902-4 (2012)

18. S. Maurice, R. C. Wiens, M. Saccoccio, B. Barraclough, O. Gasnault, et al., The ChemCam Instrument Suite on the Mars Science Laboratory (MSL) Rover: Science objectives and mast unit description. Space Sci. Rev. 170, 95-166, doi: 10.1007/s11214-012-9912-2 (2012).

19. S. M. McLennan, R. Anderson, J. F. Bell III, J. C. Bridges, J. L. Campbell, et al., Elemental Geochemistry of Sedimentary Rocks in Yellowknife Bay, Gale Crater, Mars. Science (this volume).

20. J. L. Campbell, G. M. Perret, R. Gellert, S. M. Andrushenko, N. L. Boyd, et al., Calibration of the Mars Science Laboratory alpha particle X-ray spectrometer. Space Sci. Rev. 170, 319340, doi: 10.1007/s11214-012-9873-5 (2012).

21. K. S. Edgett, R. A. Yingst, M. E. Minitti, M. L. Robinson, M. R. Kennedy, et al., Curiosity's Mars Hand Lens Imager (MAHLI): Initial observations and activities. Lunar Planet. Sci. Conf. 44, abst. \#1199 (2013).

22. S. J. Chipera and D. L. Bish, FULLPAT: A full-pattern quantitative analysis program for Xray powder diffraction using measured and calculated patterns. J. Applied Crystallography 35, $744-749$ (2002). 
23. D. L. Bish, D. F. Blake, D. T. Vaniman, S. J. Chipera, R. V. Morris, et al., X-Ray Diffraction Results from Mars Science Laboratory: Mineralogy of Rocknest at Gale Crater. Science 341, DOI: 10.1126/science.1238932 (2013).

24. See supplementary materials on Science Online.

25. R. V. Morris, D. W. Ming, D. F. Blake, D. T. Vaniman. D. L. Bish, et al., The amorphous component in martian basaltic soil in global perspective from MSL and MER missions. Lunar Planet. Sci. Conf. 44, abst. \#1653 (2013).

26. S. M. Morrison, R. T. Downs, D. F. Blake, D. L. Bish, D. W. Ming, et al., Crystal-chemical analysis of soil at Rocknest, Gale crater. Lunar Planet. Sci. Conf. 44, abst. \#1831 (2013).

27. M. S. Rice and J. F. Bell III, Mapping Hydrated Materials with MER Pancam and MSL Mastcam: Results from Gusev Crater and Meridiani Planum, and Plans for Gale Crater, Amer. Geophys. Union Fall Mtg., abst. \#P22A-02 (2011).

28. N. T. Skipper, K. Refson, and J. D. C. McConnell, Computer simulation of interlayer water in 2:1 clays. J. Chem. Phys. 94, 7434-7445 (1991).

29. J. Janchen, D. L. Bish, D. T. F. Möhlmann, and H. Stach, Investigation of the water sorption properties of Mars-relevant micro- and mesoporous minerals. Icarus 180, 353-358 (2006).

30. D. L. Bish, J. W. Carey, D. T. Vaniman, and S. J. Chipera, Stability of hydrous minerals on the martian surface. Icarus 164, 96-103 (2003).

31. C. I. Rich, Hydroxy interlayers in expansible layer silicates. Clays and Clay Min. 16, 15-30 (1968).

32. B. F. Jones and A. H. Weir, Clay minerals of Lake Abert, an alkaline, saline lake. Clays and Clay Min. 31, 161-172 (1983).

33. D. R. Pevear, D. P. Dethier, and D. Frank, Clay minerals in the 1980 deposits from Mount St. Helens. Clays and Clay Min. 30, 241-252 (1982).

34. R. S. McQuivey and T. N. Keefer, The relation of turbulence to deposition of magnetite over ripples. U.S. Geol. Surv. Prof. Pap. 650-D, D244-D247 (1969).

35. R. Slingerland and N. D. Smith, Occurrence and formation of waterlaid placers, Ann. Rev. of Earth and Planetary Sci. 14, 113-147 (1986).

36. T. D. Glotch and M. D. Kraft, Thermal transformations of akaganéite and lepidocrocite to hematite: assessment of possible precursors to Martian crystalline hematite. Phys. Chem. Minerals 35, 569-581 (2008). 
37. N. Matsuo, New mineral akaganeite, beta-FeOOH, from Akagane Mine, Iwate Prefecture, Japan. Japanese Association of Mineralogists, Petrologists, and Economic Geologists 59, 143-151 (1968).

38. S. W. Squyres, R. E. Arvidson, J. F. Bell III, F. Calef III, B. C. Clark, et al., Ancient Impact and Aqueous Processes at Endeavour Crater, Mars. Science 336, 570-576 (2012).

39. Y. Langevin, F. Poulet, J.-P. Bibring, and B. Gondet, B., Sulfates in the north polar region of Mars detected by OMEGA/Mars Express. Science 307, 1584-1586 (2005).

40. J. W. Wray, S. W. Squyres, L. H. Roach, J. L. Bishop, J. F. Mustard, and E. Z. Noe Dobrea, Identification of the Ca-sulfate bassanite in Mawrth Vallis, Mars. Icarus 209, 416-421 (2010).

41. J. F. Bell III, M. C. Malin, M. A. Caplinger, M. A. Ravine, A. S. Godber, M. C. Jungers, M. S. Rice, and R. B. Anderson, Mastcam Multispectral Imaging on the Mars Science Laboratory Rover: Wavelength Coverage and Imaging Strategies at the Gale Crater Field Site. Lunar Planet. Sci. Conf. 43, abst. \#2541 (2012).

42. P. W. Mirwald, Experimental study of the dehydration reactions gypsum-bassanite and bassanite-anhydrite at high pressure: Indication of anomalous behavior of $\mathrm{H}_{2} \mathrm{O}$ in the temperature range of 50-300 ${ }^{\circ} \mathrm{C}$. J. Chem. Physics 128, doi 10.10631/1.2826321 (2008).

43. D. T. Vaniman, D. L. Bish, and S. J. Chipera, Bassanite on Mars. Lunar Planet. Sci. Conf. 40, \#1654 (2009).

44. K. Robertson and D. Bish, Constraints on the distribution of $\mathrm{CaSO}_{4} \bullet \mathrm{nH}_{2} \mathrm{O}$ phases on Mars and implications for their contribution to the hydrological cycle. Icarus 223, 407-417 (2013).

45. D. T. Vaniman and S. J. Chipera, Transformations of Mg- and Ca-sulfate hydrates in Mars regolith. Amer. Min. 91, 1628-1642 (2006).

46. D. T. Vaniman and S. J. Chipera, Rates and modes of hydration in Mg- and Ca-sulfates on Mars. Workshop on Sulfates as Recorders of Atmospheric-Fluid-Rock Interactions, Lunar and Planetary Inst., abst. \#7023 (2006).

47. A. Gunatilaka, A. Al-Temeemi, and A. Saleh, A new occurrence of bassanite in recent evaporitic environments, Kuwait, Arabian Gulf. Kuwait J. Sci. 12, 157-166 (1985).

48. S. Douglas and H. Yang, Mineral biosignatures in evaporites: Presence of rosickyite in an endoevaporitic microbial community from Death Valley, California, Geology 30, 1075-1078 (2002).

49. T. Worku and A. Parker, Occurrence of bassanite in Lower Lyas rocks of the Lyme Regis area, England. Min. Mag. 56, 258-260 (1992). 
50. M. Glamoclija, M. L. Fogel, A. Kish, and A. Steele, Microbial signatures from the arid environments of White Sands National Monument, New Mexico. Astrobiology Science Conference 2010: Evolution and Life: Surviving Catastrophes and Extremes on Earth and Beyond, Lunar and Planetary Inst., abst. \#5460 (2010).

51. F. Mees and M. De Dapper, Vertical variations in bassanite distribution patterns in nearsurface sediments, southern Egypt. Sed. Geol. 181, 225-229 (2005).

52. A. C. McAdam, L. A. Leshin, R. P. Harvey, and E. J. Hoffman, Antarctic soil derived from the Ferrar Dolerite and implications for the formation of martian surface materials. Second Conference on Early Mars: Geologic, Hydrologic, and Climatic Evolution and the Implications for Life, Lunar and Planetary Inst., abst. \#8050 (2004).

53. M. Oetzel, G. Heger, and T. Koslowski, Influence of ambient moisture and temperature on the phase transitions in the $\mathrm{CaSO}_{4}-\mathrm{H}_{2} \mathrm{O}$ system. ZKG International 53. 354-361 (2000).

54. L. A. Hardie, The gypsum-anhydrite equilibrium at one atmosphere pressure. Am. Min. 52, 171-200 (1967).

55. R. G. Burns, Rates and mechanisms of chemical weathering of ferromagnesian silicate minerals on Mars, Geochim. Cosmochim. Acta 57, 4555-4574 (1993).

56. M. Y. Zolotov and M. V. Mironenko, Timing of acid weathering on Mars: A kineticthermodynamic assessment. J. Geophys. Res. 112, doi:10.1029/2006JE002882 (2007).

57. S. M. McLennan, J. F. Bell III, W. M. Calvin, P. R. Christensen, B. C. Clark, et al., Provenance and diagenesis of the evaporite-bearing Burns formation, Meridiani Planum, Mars. Earth Planet. Sci. Lett. 240, 95-121 (2005).

58. R. E. Milliken, D. L. Bish. T. Bristow, and J. F. Mustard, The case for mixed-layered clays on Mars. Lunar Planet. Sci. Conf. 41, \#2030 (2010).

59. T. F. Bristow and R. E. Milliken, Terrestrial perspective on authigenic clay mineral production in ancient martian lakes. Clays and Clay Min. 59, 339-358 (2011).

60. L. P. Keller, K. L. Thomas, R. N. Clayton, T. K. Mayeda, J. M. DeHart, and D. S. McKay, Aqueous alteration of the Bali CV3 chondrite: Evidence from mineralogy, mineral chemistry, and oxygen isotope compositions. Geochim. Cosmochim. Acta 58, 5589-5598 (1994).

61. H. K. Chang, F. T. Mackenzie, and J. Schoonmaker, Comparisons between the diagenesis of dioctahedral and trioctahedral smectite, Brazilian offshore basins. Clays and Clay Min. 34, 407-423 (1986).

62. B. C. Hahn, H. Y. McSween, and N. J. Tosca, Constraints on the stabilities of observed martian secondary mineral phases from geothermal gradient models. Lunar Planet. Sci. Conf. 42, abst. \#2340 (2011). 
63. J.-P. Bibring, Y. Langevin, J. F. Mustard, F. Poulet, R. Arvidson, et al., Global mineralogical and aqueous Mars history derived from OMEGA/Mars Express data. Science 312, 400-404 (2006).

64. B. J. Thomson, N. T. Bridges, R. Milliken, A. Baldridge, S. J. Hook, J. K. Crowley, G. M. Marion, C. R. de Souza Filho, A.J. Brown, and C. M. Weitz, Constraints on the origin and evolution of the layered mound in Gale crater, Mars using Mars Reconnaissance Orbiter data. Icarus 214, 413-432, doi:10.1016/j.icarus.2011.05.002 (2011).

65. R. N. Clark, G. A. Swayze, R. Wise, E. Livo, T, Hoefen, et al., U.S. Geological Survey, USGS Digital Spectral Library 06; http://speclab.cr.usgs. gov/spectral.lib06.force (2007).

66. J. F. Bell III, S. W. Squyres, K. E. Herkenhoff, J. N. Maki, H. M. Arneson, et al., The Mars Exploration Rover Athena Panoramic Camera (Pancam) Investigation, J. Geophys. Res. 108 (E12), doi:10.1029/2003JE002070 (2003).

67. J. F. Bell III, D. Savransky, and M. J. Wolff, Chromaticity of the martian sky as observed by the Mars Exploration Rover Pancam instruments, J. Geophys. Res. 111, E12S05, doi:10.1029/2006JE002687 (2006).

68. A. Wang, J. F. Bell III,_R. Li, J. R. Johnson, W. Farrand, R. E. Arvidson, L. Crumpler, S. W. Squyres, K. E. Herkenhoff, A. Knudson, W. Chen, and the MER/Athena Science Team, Light-toned salty soils and co-existing silica-rich species discovered by the Mars Exploration Rover Spirit in Columbia Hills, J. Geophys. Res. 113, E12S40, doi:10.1029/2008JE003126 (2008).

69. S.W. Ruff, J. D. Farmer, W. M. Calvin, K. E. Herkenhoff, J. R. Johnson, et al., Characteristics, distribution, origin, and significance of opaline silica observed by the Spirit rover in Gusev crater, Mars, J. Geophys. Res. 116, E00F23. doi:10.1029/2010JE003767 (2011).

70. R. E. Arvidson, J. W. Ashley, J. F. Bell III, M. Chojnacki, J. Cohen, et al., Opportunity Mars Rover mission: Overview and selected results from Purgatory ripple to traverses to Endeavour crater, J. Geophys. Res. 116, E00F15, doi:10.1029/2010JE003746 (2011).

Acknowledgments: This paper was significantly improved by comments and recommendations from two anonymous reviewers. Support from the NASA Mars Science Laboratory Mission is gratefully acknowledged. Some of this research was carried out at the Jet Propulsion Laboratory, California Institute of Technology, under a contract with the National Aeronautics and Space Administration. 


\section{Figures}
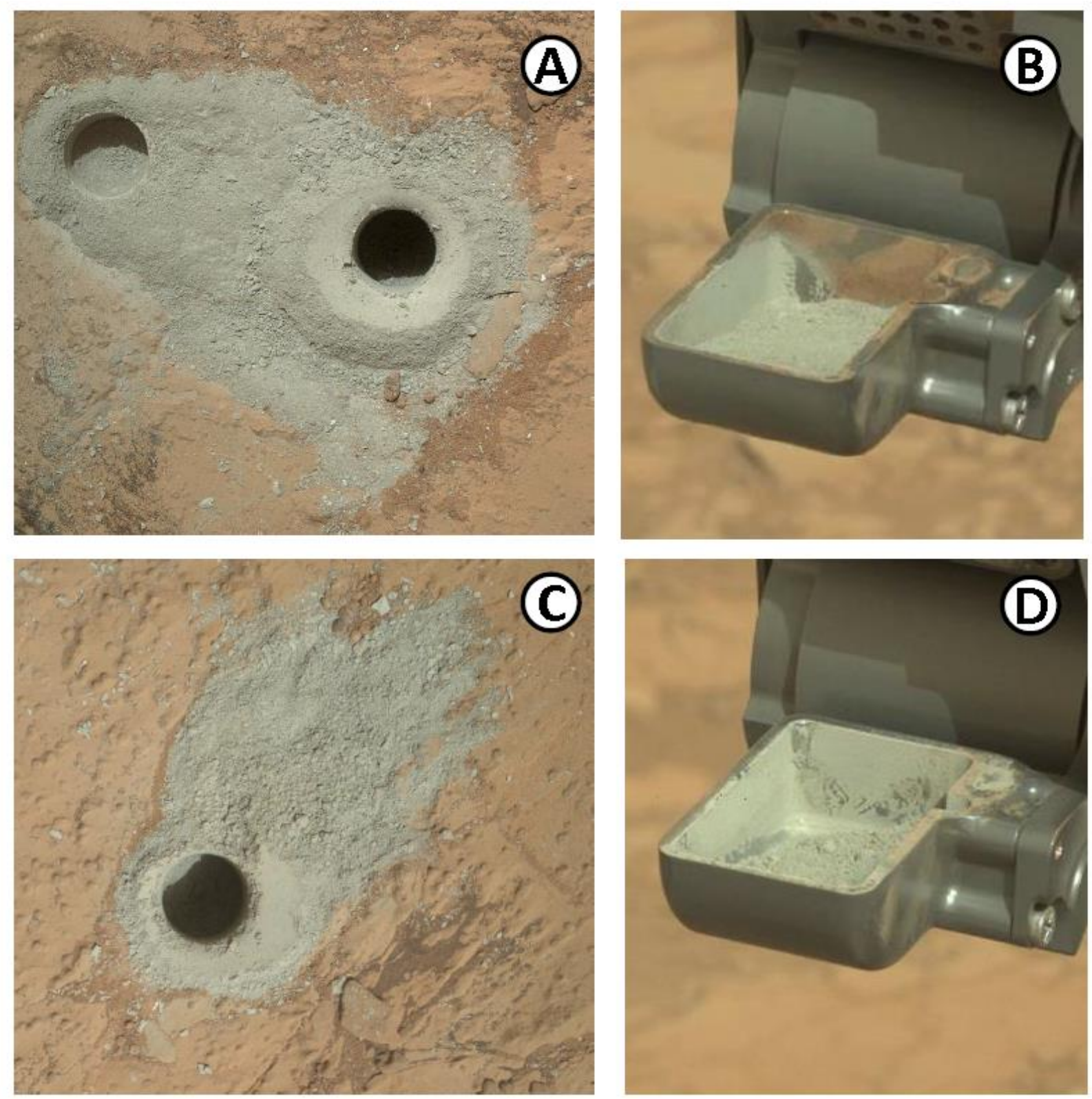

Fig. 1. Images of mudstone drill holes and drill powders. (A) shallow (1-cm deep) test drill hole (at left) and sampled drill hole (6.5-cm deep) for John Klein. (B) John Klein drill sample in the scoop reservoir before sieving to $<150 \mu \mathrm{m}$. (C) sampled drill hole for Cumberland, and (D) Cumberland drill sample in the scoop reservoir before sieving to $<150 \mu \mathrm{m}$. Borehole diameters are $1.6 \mathrm{~cm}$. Scoop inner width is $3.8 \mathrm{~cm}$. Images used in this composite are: A = MAHLI image sol 182, B = Mastcam $34 \mathrm{~mm}$ image sol 193, C = MAHLI image sol 279, D = Mastcam $34 \mathrm{~mm}$ image sol 279. 

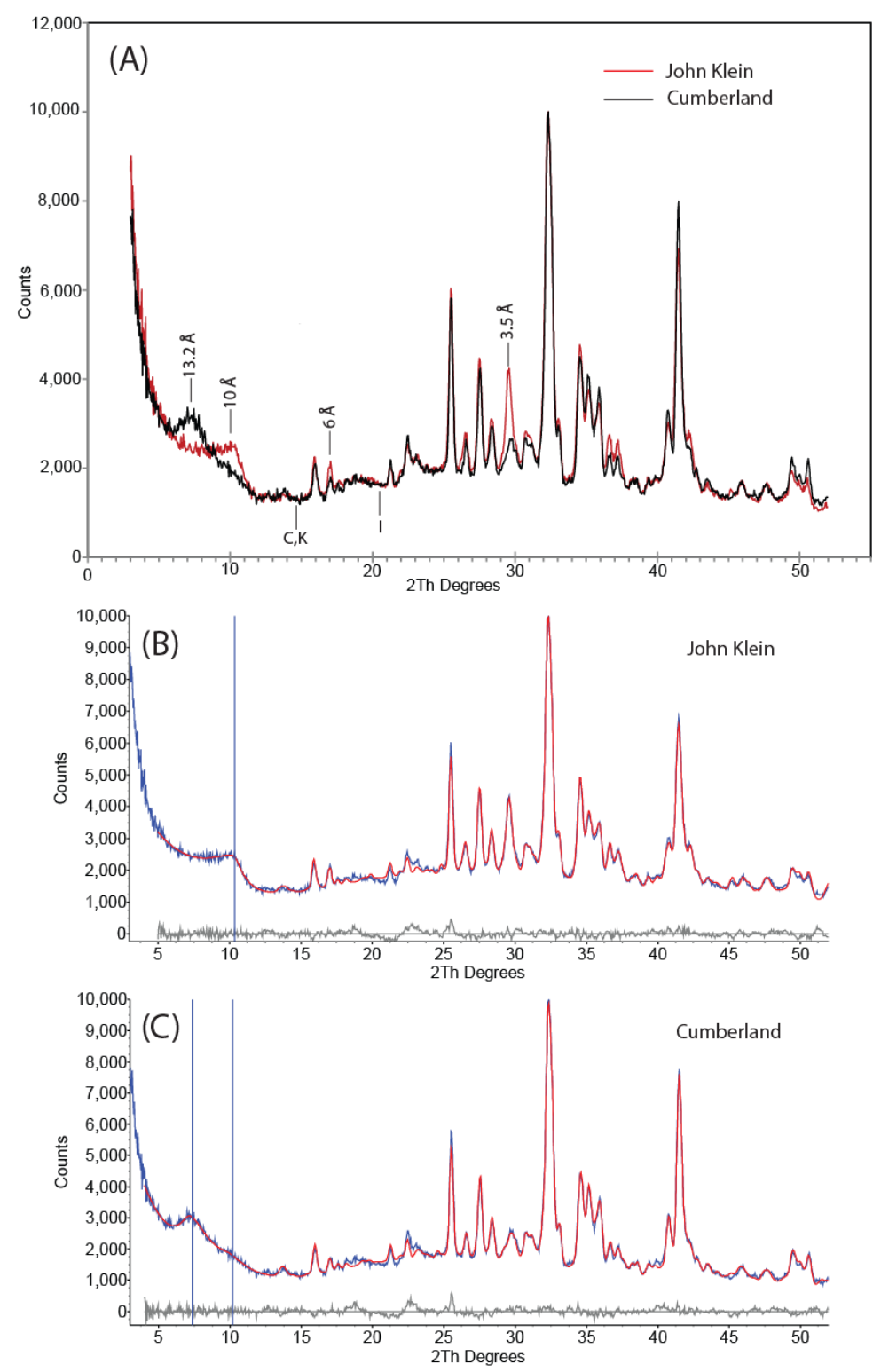

Fig. 2. X-ray diffraction patterns of mudstone samples. (A) X-ray diffraction patterns for John Klein and Cumberland superimposed. Similarity between the mudstone samples is evident but there are notable differences in the major smectite 001 peaks at $13.2 \AA$ in Cumberland and at $10 \AA$ in John Klein (spacing corrected for Lorentz polarization). Also labeled are reflections at $6 \AA$ for bassanite and $3.5 \AA$ for anhydrite plus Fe-forsterite, which are more abundant in John Klein than in Cumberland. Letters beneath the patterns indicate where major reflections would occur for chlorite or kaolinite $(\mathrm{C}, \mathrm{K}$, at $7 \AA$ ), and illite/mica (I, at $5 \AA$ ). (B) Rietveld refinement results for John Klein and (C) Cumberland, showing observed (blue) versus calculated (red) patterns, with difference curves at the bottom (gray). Vertical scales show intensity; horizontal scales are $2 \theta$ (Co K $\alpha$ ). Vertical lines mark the position of the broad 001 basal reflection of collapsed smectite at $10 \AA$ in John Klein and, in Cumberland, a prominent peak at lower $2 \theta(13.2 \AA)$ with a more subdued peak at higher $2 \theta(10 \AA)$. 


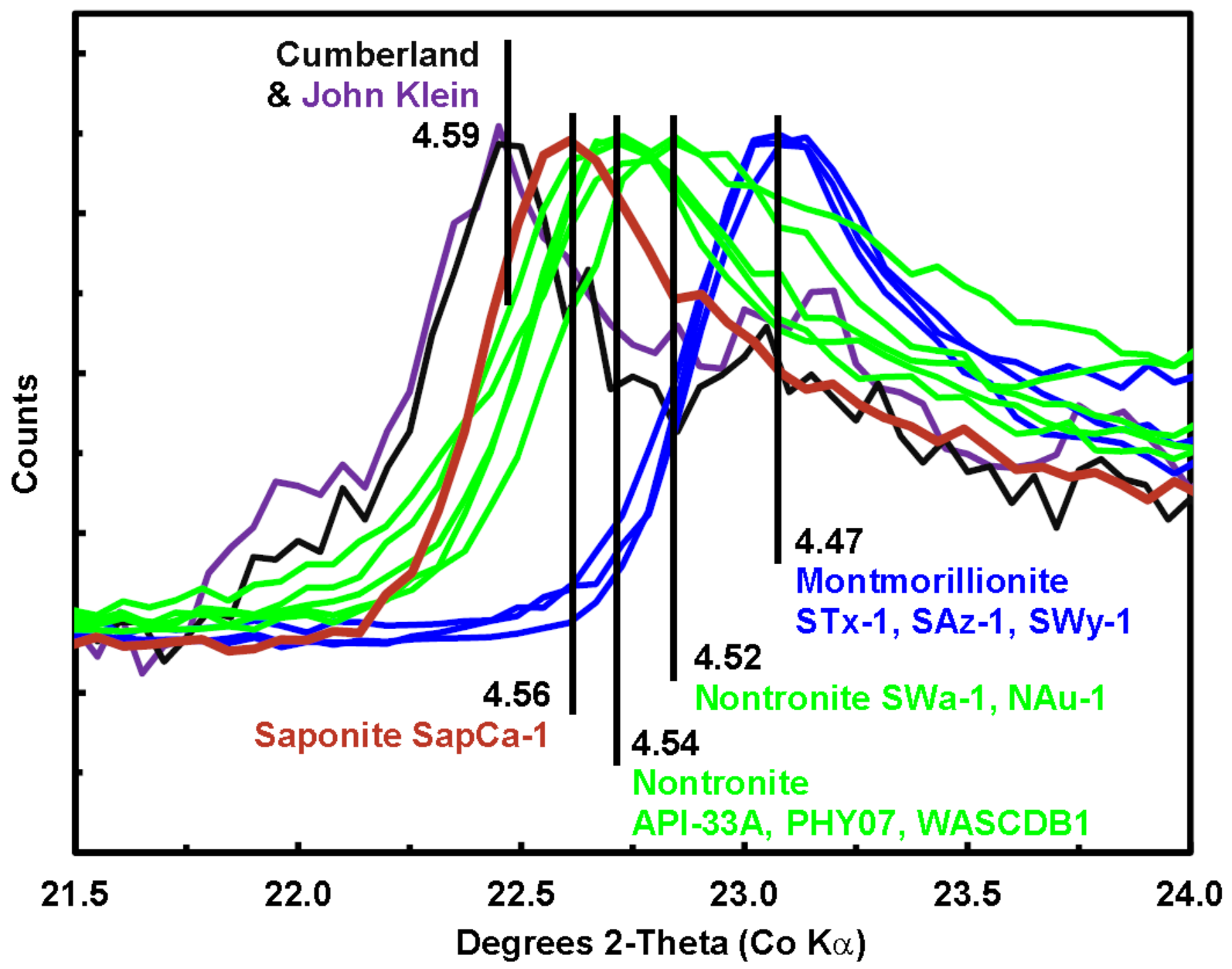

Fig. 3. Comparison of $02 l$ diffraction bands of John Klein and Cumberland with other smectites. The 2-Theta range is selected to contain the maximum intensity positions (in $\AA$ ) and profiles of the $02 l$ diffraction bands. Smectites used for comparison include a range of trioctahedral (e.g., saponite SapCa-1) to dioctahedral (e.g., montmorillonite STx-1) smectites. 

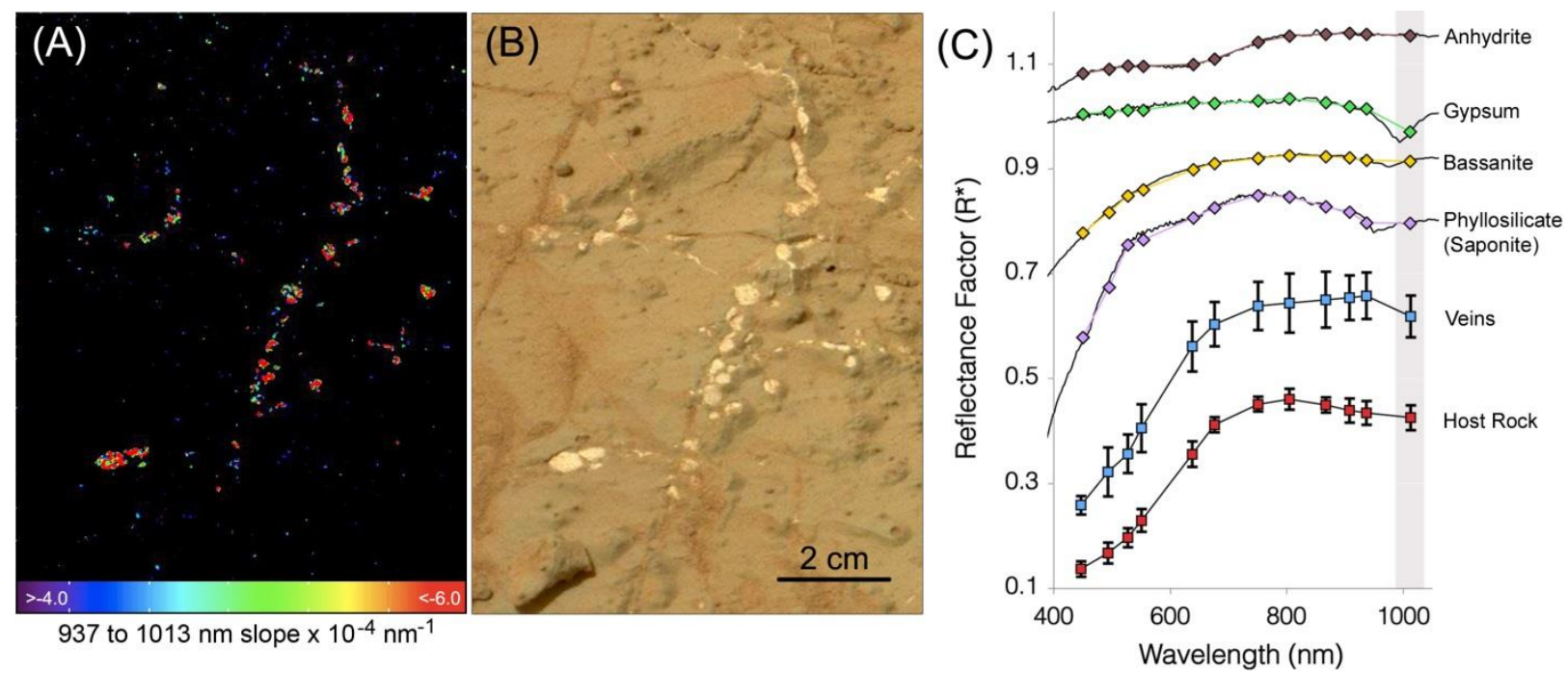

Fig. 4. Mastcam "hydration signature" data for veins in the Sheepbed unit at the target "Knorr" acquired on sol 133, sequence mcam00805. (A) Colors indicate regions where the 937- to 1013-nm spectral slope is negative and below a threshold consistent with the spectra of many hydrated minerals (24). (B) Mastcam R0 color image of the Knorr veins at the same scale as in (A). (C) Comparison of Mastcam relative reflectance $\left[\mathrm{R}^{*}(24)\right]$ spectra of the Knorr veins and host rock with laboratory reflectance spectra (65) of three Ca-sulfates with different states of hydration and a representative hydroxylated phyllosilicate (saponite). Solid lines are full-resolution lab spectra; diamonds indicate lab spectra values convolved to Mastcam bandpasses; vertical gray line indicates location of Mastcam hydration band. The anhydrite and gypsum data are offset by +0.25 and +0.1 reflectance units, respectively. Error bars in the Mastcam spectra represent the standard deviations of the group of pixels sampled. 


\section{Tables}

Table 1: Crystalline and amorphous components (wt\%) of the John Klein and Cumberland drill powders, compared with the Rocknest scooped eolian deposit (23).

\begin{tabular}{lccc}
\hline Mineral & Rocknest & John Klein & Cumberland \\
\hline Plagioclase & 29.8 & 22.4 & 22.2 \\
Fe-forsterite & 16.4 & 2.8 & 0.9 \\
Augite & 10.7 & 3.8 & 4.1 \\
Pigeonite & 10.1 & 5.6 & 8.0 \\
Orthopyroxene & & 3.0 & 4.1 \\
Magnetite & 1.5 & 3.8 & 4.4 \\
Anhydrite & 1.1 & 2.6 & 0.8 \\
Bassanite & & 1.0 & 0.7 \\
Quartz & 1.0 & $0.4^{*}$ & $0.1^{*}$ \\
Sanidine & $0.9 *$ & 1.2 & 1.6 \\
Hematite & $0.8^{*}$ & $0.6^{*}$ & 0.7 \\
Ilmenite & $0.7^{*}$ & & $0.5^{*}$ \\
Akaganeite & & 1.1 & 1.7 \\
Halite & & $0.1^{*}$ & $0.1^{*}$ \\
Pyrite & & $0.3^{*}$ & 1.0 \\
Pyrrhotite & & 22 & 31 \\
Smectite & & & \\
Amorphous & 27 & & \\
\hline
\end{tabular}

Relative $2 \sigma$ errors are comparable to those cited in (22). From plagioclase to pyrrhotite the estimated errors are $\sim 6 \%$ of the amount shown for abundances $>20 \%, \sim 15 \%$ for abundances of $10-20 \%, \sim 25 \%$ for abundances of $2-10 \%$, and $\sim 50 \%$ for abundances $<2 \%$ but above detection limit. Phases marked $(*)$ are at or near detection limit. Relative $2 \sigma$ errors are $\sim 50 \%$ of the amount shown for smectite and $\sim 60 \%$ for the amorphous component. 
Table 2: Refined unit-cell parameters for some of the major crystalline phases in the Rocknest soil compared with those for the John Klein and Cumberland mudstone samples.

\begin{tabular}{|c|c|c|c|c|}
\hline Mineral & Parameter & Rocknest & John Klein & Cumberland \\
\hline \multirow[t]{3}{*}{ Fe-forsterite } & $a(\AA)$ & $10.327(7)$ & $10.323(13)$ & $10.360(34)$ \\
\hline & $b(\AA)$ & $6.034(7)$ & $6.048(8)$ & $6.035(24)$ \\
\hline & $c(\AA)$ & $4.771(5)$ & $4.793(10)$ & $4.798(23)$ \\
\hline \multirow[t]{6}{*}{ Plagioclase } & $a(\AA)$ & $8.177(6)$ & $8.183(5)$ & $8.175(4)$ \\
\hline & $b(\AA)$ & $12.868(9)$ & $12.891(8)$ & $12.887(6)$ \\
\hline & $c(\AA)$ & $7.113(5)$ & $7.127(5)$ & $7.127(4)$ \\
\hline & $\alpha\left(^{\circ}\right)$ & $93.43(4)$ & $93.46(5)$ & $93.49(4)$ \\
\hline & $\beta\left(^{\circ}\right)$ & $116.26(2)$ & $116.29(2)$ & $116.34(2)$ \\
\hline & $\gamma\left({ }^{\circ}\right)$ & $90.13(3)$ & $90.03(4)$ & $90.04(3)$ \\
\hline \multirow[t]{4}{*}{ Augite } & $a(\AA)$ & 9.782(9) & $-*$ & $9.796(13)$ \\
\hline & $b(\AA)$ & $8.939(9)$ & - & $8.960(13)$ \\
\hline & $c(\AA)$ & $5.269(7)$ & - & $5.243(9)$ \\
\hline & $\beta\left(^{\circ}\right)$ & $106.25(9)$ & - & $105.94(11)$ \\
\hline \multirow[t]{4}{*}{ Pigeonite } & $a(\AA)$ & $9.652(9)$ & $9.698(15)$ & $9.698(12)$ \\
\hline & $b(\AA)$ & $8.92(1)$ & $8.925(13)$ & $8.925(12)$ \\
\hline & $c(\AA)$ & $5.254(7)$ & $5.230(8)$ & $5.230(7)$ \\
\hline & $\beta\left(^{\circ}\right)$ & 108.0(1) & $108.7(1)$ & $108.5(1)$ \\
\hline Magnetite & $a(\AA)$ & $8.39(2)$ & $8.384(5)$ & $8.383(3)$ \\
\hline
\end{tabular}

*Cell parameters for the augite in John Klein had large errors and therefore are not reported. 
Table 3: Compositions of major crystalline phases in the Rocknest soil compared with those for the John Klein and Cumberland mudstone samples, based on unit-cell parameters in Table 2.

\begin{tabular}{lc}
\hline \multicolumn{1}{c}{ Rocknest } \\
\hline Fe-forsterite & $\left(\mathrm{Mg}_{0.62(3)} \mathrm{Fe}_{0.38}\right)_{2} \mathrm{SiO}_{4}$ \\
Plagioclase & $\left(\mathrm{Ca}_{0.57(13)} \mathrm{Na}_{0.43}\right)\left(\mathrm{Al}_{1.57} \mathrm{Si}_{2.43}\right) \mathrm{O}_{8}$ \\
Augite & $\left(\mathrm{Ca}_{0.75(4)} \mathrm{Mg}_{0.88(10)} \mathrm{Fe}_{0.37)} \mathrm{Si}_{2} \mathrm{O}_{6}\right.$ \\
Pigeonite & $\left(\mathrm{Mg}_{1.13(9)} \mathrm{Fe}_{0.68(10)} \mathrm{Ca}_{0.19)} \mathrm{Si}_{2} \mathrm{O}_{6}\right.$ \\
\hline
\end{tabular}

\section{John Klein}

\begin{tabular}{ll}
\hline Fe-forsterite & $\left(\mathrm{Mg}_{0.51(5)} \mathrm{Fe}_{0.49}\right) \mathrm{SiO}_{4}$ \\
Plagioclase & $\left(\mathrm{Ca}_{0.44(12)} \mathrm{Na}_{0.56}\right)\left(\mathrm{Al}_{1.44} \mathrm{Si}_{2.56}\right) \mathrm{O}_{8}$ \\
Pigeonite & $\left(\mathrm{Mg}_{1.08(12)} \mathrm{Fe}_{0.82(7)} \mathrm{Ca}_{0.10}\right) \mathrm{Si}_{2} \mathrm{O}_{6}$ \\
\hline
\end{tabular}

\section{Cumberland}

\begin{tabular}{ll}
\hline Fe-forsterite & $\left(\mathrm{Fe}_{0.54} \mathrm{Mg}_{0.46(12)}\right)_{2} \mathrm{SiO}_{4}$ \\
Plagioclase & $\left(\mathrm{Ca}_{0.43(11)} \mathrm{Na}_{0.57}\right)\left(\mathrm{Al}_{1.43} \mathrm{Si}_{2.57}\right) \mathrm{O}_{8}$ \\
Augite & $\left(\mathrm{Ca}_{0.82(5)} \mathrm{Mg}_{0.68(13)} \mathrm{Fe}_{0.50}\right) \mathrm{Si}_{2} \mathrm{O}_{6}$ \\
Pigeonite & $\left(\mathrm{Mg}_{1.08(11)} \mathrm{Fe}_{0.80(6)} \mathrm{Ca}_{0.12}\right) \mathrm{Si}_{2} \mathrm{O}_{6}$ \\
\hline
\end{tabular}

